Article

\title{
The Impact of Corporate Governance Structures on Foreign Direct Investment: A Case Study of West African Countries
}

\author{
Seth Nana Kwame Appiah-Kubi ${ }^{1, * \mathbb{D}}$, Karel Malec ${ }^{1}\left(\mathbb{D}\right.$, Mansoor Maitah ${ }^{1}{ }^{1}$, \\ Sandra Boatemaa Kutin ${ }^{2}$, Ludmila Pánková ${ }^{1}$, Joseph Phiri ${ }^{1}$ (D) and Orhan Zaganjori ${ }^{1}$ (I) \\ 1 Department of Economics, Faculty of Economics and Management, Czech University of Life, 16500 Prague, \\ Czech Republic; maleck@pef.czu.cz (K.M.); maitah@pef.czu.cz (M.M.); pankoval@pef.czu.cz (L.P.); \\ phiri@pef.czu.cz (J.P.); zaganjori@pef.czu.cz (O.Z.) \\ 2 Department of Finance, College of Humanities, University of Ghana Business School, P. O. Box LG 78, Legon, \\ Accra 00233, Ghana; sbkutin@st.ug.edu.gh \\ * Correspondence: appiah-kubi@pef.czu.cz
}

Received: 27 February 2020; Accepted: 27 April 2020; Published: 4 May 2020

check for updates

\begin{abstract}
A number of studies have been done to examine the factors that impact the level of foreign direct investment in African countries. However, most of them have not considered the effect corporate governance structures have on foreign direct investment (FDI) in their estimations. This research therefore pursued the investigation of the relationship between corporate governance structures at the national level and foreign direct investment concentrating mainly on West African economies for the period 2009-2018. The study constructed a panel, sampling annual data from 17 West African countries. The System generalized method of moments (GMM) was used in analyzing the panel data to attain the objective of the research. The results of the study reveal that countries characterized by greater protection of the interest of non-controlling parties are able to accumulate progressive FDIs. Economies with firms portraying high ethical values also generally generate increasing foreign direct investment, and the existence of effective boards also significantly improves the country's FDI inflows. Finally, the findings report that the impact of regulations in securities and the stock exchange on FDI is insignificant. The study recommends that West African countries institute corporate governance structures purely independent of political influences in order to ensure effective utilization of foreign direct investment to mitigate poverty.
\end{abstract}

Keywords: foreign direct investment (FDI); West Africa; macro level corporate governance; economic development; corporate governance structure

\section{Introduction}

Just like any organization, every country has an objective to attain economic development. As such, countries undertake projects that will boost economic development. According to a report by The United Nations Economic Commission for Africa (UNECA) [1], industrialization is one way of improving development in Africa. Industrialization focuses on expanding activities in the manufacturing sector, which calls for high financial and technological investment [2]. Considering the limited funds available to undertake these expansionary activities in the continent, most countries fall on foreign direct investments to bridge the gap [3]. Foreign direct investment, which is an investment made by a non-resident to have a controlling interest in the management of an organization has, therefore, become crucial in the running of developing economies, especially with the help of globalization [2]. 
Foreign direct investment in Africa has been rising in recent decades. During 2014, Africa had a 65\% proportion of foreign direct investments (FDIs). Between 2014 and 2015, FDIs on the continent rose by $40 \%$ [4]. In 2018, although there was a global fall in FDIs, Africa experienced an approximate $11 \%$ increase in total FDI inflows compared to the previous year $[5,6]$. According to Globerman et al., in 2015 Africa recorded a 6\% rise in the number of foreign companies established compared to the 2014 value of 495 companies [7]. FDIs have out-performed other external financing sources such as official development assistance (ODA) in developing economies in which Africa cannot be exempted [7]. FDI is preferred over other capital inflows because there is low risk of fluctuation shocks, which makes it more stable [8]. The United Nations Sustainable Development Goals (UNSDG) for Africa recommended the need for African economies to attract a significant amount of foreign direct investment (FDI) to improve growth through investment in important development infrastructure. African countries are performing poorly compared to their peers in terms of infrastructure. Being predominantly agricultural economies, it would mean that these African countries must work to expand their economy if they want to achieve Sustainable Development Goal 8 of achieving GDP growth of $8 \%$ [9].

There are many benefits attributed to FDI, which include job creation, technology transfer, capital formation, and higher export [10]. FDI inflow in the continent has also contributed to the steady economic growth the continent has experienced [7]. An increase in FDI will enable the continent in the attainment of the Sustainable Development Goal by 2030 [10]. According to the United Nations Conference on Trade and Development (UNCTAD), FDI causes forward and backward linkages where multinational companies employ input resources from local firms, therefore improving domestic firm performance and efficiency [5]. According to Appiah-Kubi et al. [11], one of the significant prerequisites for improvement is the capacity to draw in foreign direct investment that can help with building development infrastructural facilities fit for upgrading sustainable development. FDI includes the preparation of investment funds from foreign investors for the host economy. This might be as a move of possession from local to remote financial investors or as an extension in productive limit and capital development in a nation. Therefore, it may likewise have suggestions for ownership, since local financial investors may need to yield corporate governance of businesses to outside investors. FDI gives a chance for speculators to expand their portfolio in this way, enhancing the harmony between risk and return [11].

Several researchers have established the importance of external development and political issues in determining the level of FDI. External developments mentioned in this study include good roads, quality electricity, and better broadcast communications infrastructures like telecommunications [10]. In their study, Dupasquier et al. found that FDI is very responsive to these external factors [4]. UNCTAD and Chuhan et al. also confirmed the results of Dupasquier et al. that the availability of roads, electricity, and other external conditions in a country are major determinants of FDI [4-6]. Institutionalization of an efficient judiciary also improves the level of FDI [7].

However, corporate governance practices in organizations will also help improve information asymmetry between foreign investors and the host country [12]. Due to this, corporate governance practices should be considered in exploring drivers of FDI. Good corporate governance eliminates adverse selection and moral hazards [13]. Domestic firms may communicate only good investment opportunities to foreign investors but hide information when it is in their self-interest. This causes an agency problem in running business operations [14]. Foreign investors are also aware that hidden information may exist that affects a high rate of return or causes firms to refuse to invest at all. Instituting good corporate governance ensures that information is well distributed and that resources are matched with potential investment, therefore mitigating conflict between the two parties [8].

Based on the above, this study examines the relationship between corporate governance and Foreign Direct Investment in Africa, specifically in West Africa. Though there has been little research on FDI and corporate governance, Johnson as well as Love and Klapper conclude that good corporate governance results in high levels of FDI; their studies were conducted in developed economies where the corporate governance practices differ significantly from developing countries [12,13]. Considering 
the difference in structures, it would be an error to generalize findings to that effect. Again, the study concentrates on West Africa because regions within Africa have attained different levels of development and therefore attract unequal FDIs. In order to avoid distortion of results, we chose to conduct the study on regional bases, which effectively groups countries with similar characteristics.

Generally, West Africa has recorded a trend of increasing FDIs over the years. Regardless, because of specific country effects, it can be observed from Figure 1 that there have been irregularities in the trends across nations. The figures below give a pictorial view of the FDI trends of 17 sampled countries for this study from 2009 to 2018. These West African countries were Benin, Burkina Faso, Cape Verde, Cameroon, Cote D'Ivoire, Gambia, Ghana, Guinea, Guinea-Bissau, Liberia, Mali, Mauritania, Nigeria, Niger, Senegal, Sierra Leone, and Togo. The vertical axes present FDI ratios plotted against the years of focus and countries on the horizontal axes. Equatorial Guinea is not included in the study due to the unavailability of data.

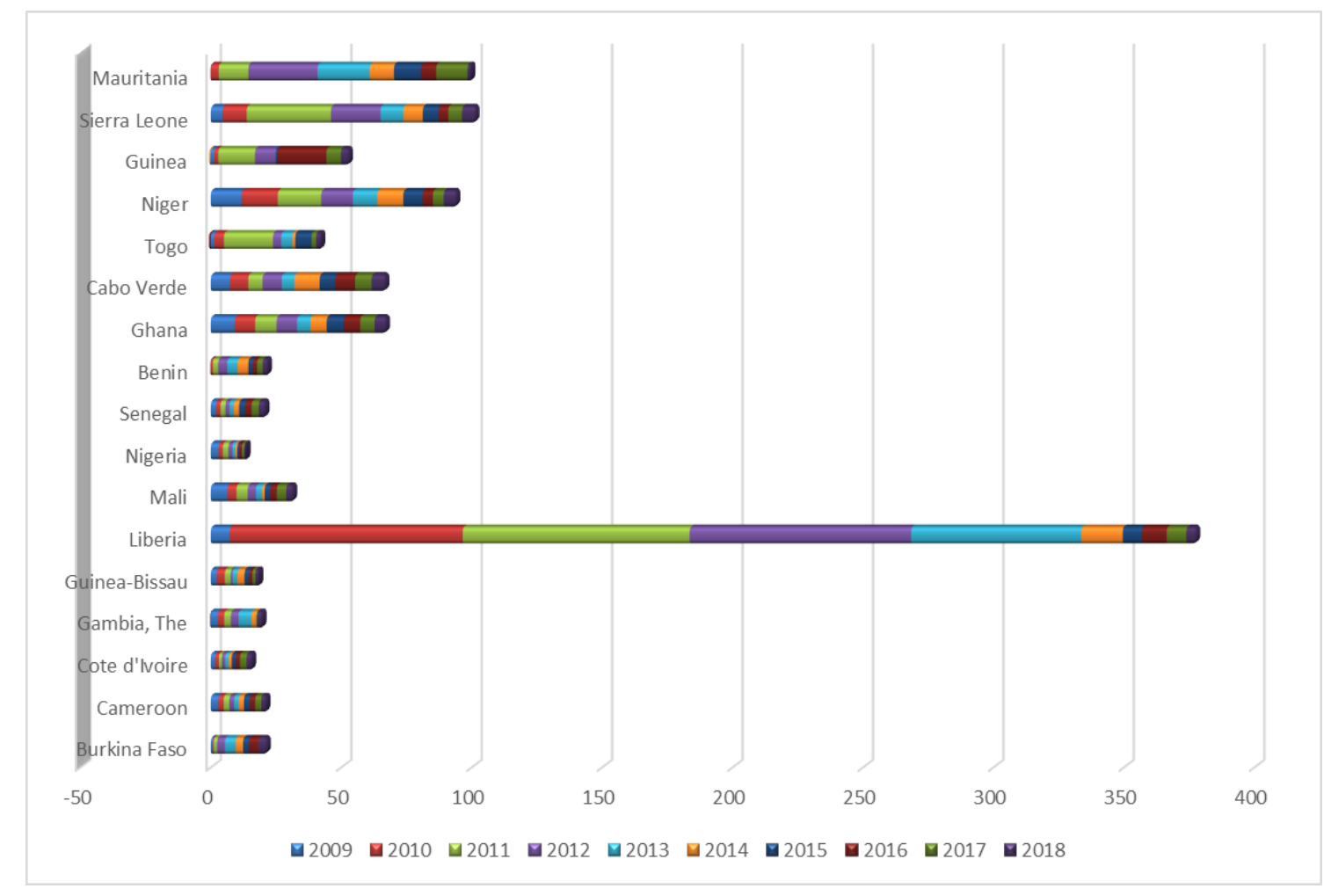

Figure 1. Foreign direct investment (FDI) net inflows in West African countries, 2009-2018 (\% of GDP).

Source: World Bank World Development Indicators (2020).

\section{Literature Review and Research Questions}

Empirical literature has discussed different determinants of FDI, and findings differ depending on the economy type and sampled countries. For instance, Saini and Singhania compared the factors that affect the level of FDI for both developed and developing countries employing a dynamic panel generalized method of moments (GMM) [15]. The study found that determinants in developed countries are more policy-related, but developing-country factors are basically economic factors. Addison and Heshmati also used GMM to assess the effect that institution quality has on FDI inflows in Vietnam [16]. The findings confirm that indeed institutional quality positively impacts the level of FDI, but the effect differs across provinces.

Appiah-Kubi et al. studied the impact of macroeconomic variables on the inflows of foreign direct investment in the least developed West African countries using a dynamic panel generalized method of moments (GMM) of 13 countries from 2000 to 2014. The authors found out that infrastructure development has a positive impact on the inflow of FDI to the least developed West African nations [11]. 
Manuel and Roberto argued the need for policies to make FDI more effective in enhancing domestic investment in developing countries [17]. The authors used empirical estimation and testing with panel data of the period 1971-2000 to examine the extent to which FDI in developing countries crowds in or crowds out domestic investment. The authors reveal that impacts of FDI on household investment are in no way, shape, or form constantly ideal, that oversimplified arrangements towards FDI are probably not going to be ideal, and, preeminently, that more consideration should be paid to financial approaches that encourage total domestic investment [17].

Agosin and Machado investigated the impact of poor governance quality on FDI in Russia by using a business survey across 40 administrative districts and estimation techniques of one-stage and two-stage instrumental variables [18]. The authors found that a higher frequency of illegal payments and higher pressure from regulatory agencies, enforcement authorities, and criminals have significantly negative effects on FDI. The authors also confirmed that the moving of governance quality from the average to the top across Russian regions more than doubles the FDI stock [18].

Barrel and Nahhas [19] in their paper also discussed the factors affecting bilateral foreign direct investment (FDI) stocks from 14 high-income countries to 31 OECD countries over the period 1995-2015 employing the generalized method of moments (GMM) estimator to a gravity model of bilateral FDI stocks. Their findings suggested that EU membership is a significant determinant of FDI and that European Integration has a large effect on FDI stocks [19].

Anghel also argued that countries whose governments are highly ranked according to various indices of the quality of institutions tend to do better in attracting foreign direct investment [20]. In an empirical analysis of cross-section data by applying estimation methods of ordinary least squares and instrumental variables, the author finds that different aspects of the quality of institutions in a country (corruption, protection of property rights, policies related to opening a business and maintaining it, etc.) are almost always significant in attracting FDI [20].

According to Bissoon, control of corruption, better rule of law, political stability, and better freedom of expression of the media are used as indicators of good governance and institutional quality [21]. The author's paper empirically studied the impact of institutional quality on FDI in 45 developing countries in Africa, Latin America, and Asia from 1996 to 2005. By using the OLS estimation, results show that the quality of some institutions in the host country have a significantly large effect on inward FDI. Although different indicators of institutional quality are complementary to each other, their combined effect is found to reinforce the level of FDI inflows to the host country.

Gradually, good corporate governance is becoming a focus when it comes to the factors informing the degree of FDI as multinationals and investors at large in recent times look out for these structures before taking decisions [22]. This has therefore seemingly rendered traditional determinants of FDI such as natural resource availability, infrastructure quality, market availability and labor cost, somewhat obsolete factors or secondary as compared to good corporate governance [23,24]. However, the link between corporate governance and FDI, especially at the national level, has been discussed in empirical literature only to a limited extent.

A few studies such as Globerman and Shapiro, Biglaiser and DeRouen, Gani, and Lee et al. have scientifically supported the idea of good corporate governance improving FDI inflows [25-28]. The predominant view is that economies characterized by means of a generally excellent corporate governance will in general pull in more prominent foreign direct investment $[7,25]$. This is on the ground that foreign investors accept that their investments cannot be protected in a financial framework described by poor corporate governance frameworks [25]. Jones and Pollitt contend that corporate disappointment is universally an outcome of the disintegration of corporate governance in economies, and thus the building of corporate governance structures in nations is crucial for organization sustenance and in the long run protecting the interests of foreign financial specialists [29]. Although there has been a competitive business condition where rivalry has become a fundamental piece of nation risk analysis process, natural resources alone cannot serve as a motivation for foreign financial investors to stream capital into a specific economy. As a result, African researchers are putting 
forth an attempt to look at the other main thrusts behind the inflow of foreign direct investment in West African economies [11].

Based on Figure 2 below, it can be observed that the inflowing FDI in Africa is highest in the West African region. Unfortunately, studies on the impact that corporate governance has on the inflows of FDI in West African countries as a whole do not exist. However, the West African region has always recorded the highest inflows of FDI for the period 2009 to 2018. It became imperative for us to do a critical study, and thus it became the foundation of our research to determine the corporate structures that determine the inflows of FDI in West Africa. The Materials and Methods section of this paper describes how the secondary research was conducted as well as the model specification. The Results and Discussion section presents the results obtained, and discussion and comparison of the results of own research with similar studies in the context of the issue are conducted. Finally, conclusion, policy implications, and direction for future research on the topic is discussed.

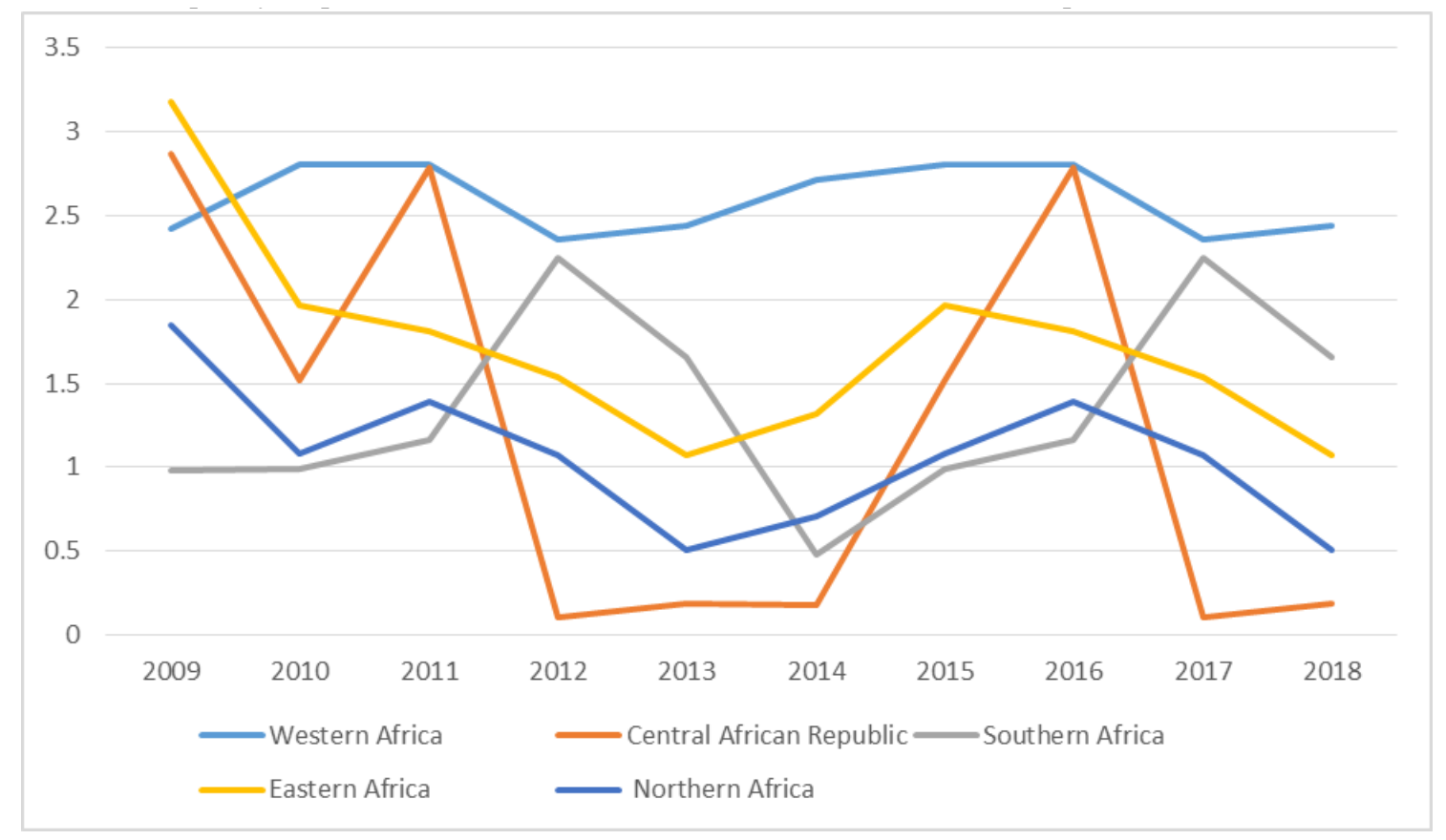

Figure 2. African sub-regional foreign direct investment net inflows from 2009 to 2018 (\% of GDP). Source: World Bank World Development Indicators from 2020.

The agency problem existing between majority and minority shareholders' interests still prevails and remains unresolved [30]. Reputable researchers in the area of corporate governance report that corporate governance protects the interest of minority shareholders in economies where legal systems are partial towards this class of stockholders [31-33]. Increasingly, countries are instituting good corporate governance structures with codes of conduct to protect minority interests [34]. These codes place both majority and minority interest on the same scale in terms of civil rights. La Porta et al. confirm that the ability for countries to attract FDIs from investors is highly contingent on how minority interest is protected or safeguarded [35]. Likewise, McLean et al. among others posit that any economy that has systems in place to protect minority interest tends to attract a lot of foreign investors [36,37]. Kim et al. maintain that protecting minority shareholders' interest has a positive impact on FDI inflows [38]. The USA government is more generous in investing when a nation strongly has the minority shareholders' interest at heart compared to those who just regard majority interests [39]. The studies referenced above show how relevant minority shareholders' interest is in the quest of exploring investment funding in any economy. The above informs the first research question of this study, which is:

Q1: Does minority shareholders' interest protection attract FDI inflows in West Africa? 
Ethical principles cannot be overlooked in attracting FDI inflows to economies, specifically developing ones. Fair and ethical dealings with stakeholders at large is established as relevant in increasing FDI inflows [40]. This implies that foreign investors look out for economies whose companies' conduct business ethically. Bardy et al. argue that companies that are involved in opportunistic activities expose themselves to attack from civil groups, non-governmental agencies, and others [41]. These activities do not make companies attractive to foreign investors, thus affecting the level of FDI. It is therefore believed that economies practicing ethics attract more foreign investment. Valdes and Foster also confirm that countries with organizations that follow codes of standards and practice responsible business are considered to attract more FDI into their respective economies [42]. Therefore, the second research question is:

Q2: Do highly ethical firms boost FDIs in West African countries?

According to Miletkov et al. [43], the existence of independent boards of directors increases the probability for a country to attract FDIs. This therefore encourages organizations in forming their councils and committees [43]. Miletkov et al. also emphasize how effective governance sends positive signals to foreign investors that the economy will do well [43]. The study further states that institutional foreign investors are optimistic about their investment given the presence of an effective board to oversee managers [43]. Considering the weak nature of protection institutions in Africa, the existence of effective boards becomes necessary in attracting FDIs [44]. The above motivates the third research question:

Q3: Does the existence of working corporate boards attract FDIs in West Africa?

Effectiveness of securities and trading regulations influence the degree of FDIs in an economy. This implies that financial assets traded on the stock exchange should be autonomous and independent from political influences [44]. Agyemang et al. concluded that investors are not willing to direct funds to economies exhibiting interference in the implementation of regulations [45]. Securities and exchanges are supposed to go about their activities in a professional manner in order to heighten investors' confidence [46]. This implies that ensuring independent dealing in regulations motivates and boosts confidence of foreign investors to invest in economies. This leads to the final research question:

Q4: Does establishment and implementation of regulations in securities exchanges impact the degree of FDI in West African countries?

\section{Materials and Methods}

\subsection{Data}

The study employs panel data from 17 countries from West Africa for 2009-2018. Data were sourced from two main databases. The dependent variable, foreign direct investment inflow data, was extracted from World Development Indicators (WDI), a database from the World Bank. It is proxied by foreign direct investment, net inflow (\% of GDP), and the predictor variables of interest, which are corporate governance variables decomposed into four variables, namely protection of minority shareholders' interests, efficacy of corporate boards, firm's ethical behavior, and regulations of the securities exchanges. Data for these variables are from the World Competitiveness Report from the World Economic Forum's Opinion Survey. The data range from 1 to 7 with 1 described as a country not doing well and 7 meaning perfection. For instance, if a country scores 1 for minority shareholder interest, it means their interest is not protected at all, but if the country scores 7 it means the interest is fully protected. These data sets were chosen because they capture both quantitative and qualitative characteristics of the prevailing environment. However, the data reflect practices that originate from past policies. Thus, the impact of existing policies is not shown and is a limitation. Despite this limitation, to ensure a fair representation, a survey was conducted to include a large number of respondents from different institutions like universities, business organizations, etc. Again, in order to curb survey bias, random selection was done in each organization. 
The study controlled for four macroeconomic factors, namely GDP per capita (current USD), country credit rating, quality of electricity supply, and inflation. These variables were selected as control variables because GDP per capita fundamentally affects FDI inflows particularly in developing countries [33,45]. Again, according to the studies of Anyanwu and Agyemang, effective macroeconomic conditions promote FDI inflow $[10,33]$. Countries labeled with high credit ratings attract considerably large amounts of FDI inflow [47]. In addition, Kim and Wu elaborated that a significant positive link exists between country credit ratings and FDI directed into the financial sector in lower-income-generating countries [48]. Inflation was also controlled for because studies have confirmed $[10,33,37]$ that inflation is one of the major macroeconomic indicators that significantly impacts FDIs. Lastly, quality of electricity cannot be ignored when dealing with FDI determinants $[24,33,45]$. Developing countries invest more domestically in the electricity sector in order to attract more FDIs, since investors care about that factor [33]. This strengthens the case for controlling this variable in the model.

\subsection{Model Specification}

In general, panel data can be defined as the pooling of observations on a cross-section of units of observation over time. This overcomes some of the limitations of using strictly cross-sectional or time-series data [49]. Panel data regressions usually take the following form:

$$
Y_{i t}=\beta_{0}+\beta_{1} X_{i, t}+v_{i t}
$$

The model assesses the relationship between the dependent variable $Y_{i, t}$ and the explanatory variable $X_{i, t}$ along both the cross-sectional dimension $i$ and the time-series dimension $t$. The disturbance/error term $v_{i, t}$ takes into account both the unobservable unit of observation-specific effects and the remainder of the disturbance [49].

Thus, the basic specification of our model is as follows:

$$
\begin{aligned}
F D I_{i, t}=\beta_{0} F D I_{i, t-1}+ & \beta_{1} E B F_{i, t}+\beta_{2} E C B_{i, t}+\beta_{3} P M_{i, t}+\beta_{4} E R S E_{i, t} \\
& +\beta_{5} \text { Control Var }_{i, t}+v_{i, t}
\end{aligned}
$$

$i$ - country of observation; Benin, Ghana, Senegal, etc.

$t$-year of observation; 2009,... 2018.

$\beta_{0}$-intercept.

$F D I_{i, t}$-foreign direct investment.

$F D I_{i, t-1}$-lag of foreign direct investment.

$E B F_{i, t}$ - ethical behavior of firms.

$E C B_{i, t}$-efficacy of corporate boards.

$P I M_{i t}$ - protection of minority shareholders' interests.

$E R S E_{i, t}$-effectiveness of regulation of securities and exchanges.

Control Var $_{i, t}$ - a vector of control variables.

$v_{i, t}$-error/disturbance term.

The use of dynamic panel generalized method of moments (GMM) estimators developed by Arellano and Bond was used in the estimation of the model [50]. The decision to use the dynamic panel estimator was made to correct simultaneity bias and other specific nations' effects. By introducing lags of the dependent variable, the problem of simultaneity bias is corrected. Again, transforming the model to the first difference eliminates country-specific effects [51]. However, GMM has been criticized for its likeliness to report wrong results when the independent variables are persistent in nature. To ensure accurate results, Arellano and Bover proposed the use of a GMM estimator [48]. The lagged differences of the independent variables are treated as an additional instrument for a level equation. 
With GMM estimation, there are two ways of proceeding, that is one-stage GMM estimation and two-stage GMM estimation. The one-stage estimation with corrected standard errors was adopted in this study. Further, the GMM system was used because it controls for endogeneity and more suitable short period studies but a large number observations (individuals) [52]. This method is therefore suitable considering the nature of the data, the relatively short period (10 years), and 17 sampled countries. The Hansen J test and the Arellano and Bond test were conducted to ensure the accuracy of the estimates. The Arellano and Bond test was used to test for the second order serial correlation [51]. The validity of the instruments and the suitability of the model were also tested using the Hansen J test.

\section{Discussion and Results}

Table 1 below illustrates our descriptive analysis of our research of the selected West African countries from 2009 to 2018. The mean recorded for FDI for our selected West African nations during the period under consideration was $6.6 \%$. This implies that African nations draw a low amount of FDI compared to other parts of the world. Our result is affirmed by the investigation by Bokpin et al. [53], which recorded a mean FDI of 5\% in the period 1996-2011. The mean for the level of protection of minority shareholders' interests in our examined countries from 2009 to 2018 was 3.7 on a scale of 1 to 7 , with standard deviation of 0.7 and maximum and minimum of 2.0 and 6.3 , which implies that the evaluated average is low and the degree of assurance of the interests of minority investors of our selected West African countries recorded moderately adequate results. The mean value of ethical behavior of companies from our selected West African countries from 2009 to 2018 was 3.5 based on a scale of 1 to 7 , with a standard deviation of 0.6 and a scope of 2.0 to 5.0. This implies that the degree of moral conduct of firms in our West African nations is moderately adequate.

Table 1. Descriptive statistics of variables (2009-2018).

\begin{tabular}{cccccc}
\hline Variable & Observations & Mean & $\begin{array}{c}\text { Standard } \\
\text { Deviation }\end{array}$ & Min & Max \\
\hline Dependent & & & & & \\
\hline $\begin{array}{c}\text { Foreign direct investment } \\
\text { Independent }\end{array}$ & 170.0 & 6.6 & 13.4 & -1.0 & 103.3 \\
\hline $\begin{array}{c}\text { Protection of minority } \\
\text { shareholders' interest }\end{array}$ & 170.0 & 3.7 & 0.7 & 2.0 & 6.3 \\
\hline Ethical behavior of firms & 170.0 & 3.5 & 0.6 & 2.0 & 5.0 \\
\hline Efficacy of corporate boards & 170.0 & 4.1 & 0.7 & 1.7 & 5.6 \\
\hline $\begin{array}{c}\text { Regulations of securities exchanges } \\
\text { Control Variables }\end{array}$ & 170.0 & 3.3 & 0.4 & 2.5 & 4.5 \\
\hline Inflation & 170.0 & 4.8 & 5.3 & -2.2 & 23.6 \\
\hline Country credit rating & 170.0 & 22.5 & 12.4 & 2.7 & 65.7 \\
\hline Gross domestic product per capita & 170.0 & 1155.7 & 792.8 & 339.1 & 3740.4 \\
\hline Quality of electricity supply & 170.0 & 2.5 & 0.7 & 1.2 & 4.4 \\
\hline$\quad$ Source: Authors' own calculation, 2020. & & & \\
\hline
\end{tabular}

As regards the effectiveness of corporate boards in our selected West African countries during our study, their mean based on the scale of 1 to 7 was 4.1, which means that our chosen West African countries are characterized by successful corporate boards of directors. Relatively, this result confirms the work of Agyemang et al. [33] and Romano [54], which shows that, as a result of weak institutions for the protection of investors' rights in emerging countries, councils play the significant role of governance systems that stimulates confidence of foreign investors. Securities regulation recorded an average value of 3.3 on a scale of 1 to 7 , with a variability level of 0.4 and a maximum and minimum of 2.5 and 4.5 , implying that our selected West African countries show a relatively satisfactory result. 
Last but not least, in relation to control variables, the average credit score, gross domestic product, inflation, and electricity quality averaged $22.5 \%, \$ 1155.7,6.6 \%$, and 2.5 , respectively (on a scale of 1 to 7).

Table 2 below shows the correlation matrix among our variables. According to Table 2, we recorded a positive correlation between ethical behavior of firms, security of minority shareholders' interests, effectiveness of corporate boards, quality of electricity, and inflation with the level of inflows of FDI in our examined West African countries. On the other hand, we recorded a negative relationship between the effectiveness of regulation of securities exchanges, credit ratings score, and GDP per capita on the inflows of foreign direct investment into our selected West African countries. The extent of the relationships among the explanatory variables is satisfactory, meaning that multicollinearity was not a significant issue. Moreover, the connection among the explanatory variables falls within the limit of 0.9 (90 percent) as recommended by Romano [54].

Table 2. The correlation matrix.

\begin{tabular}{|c|c|c|c|c|c|c|c|c|c|}
\hline Variables & FDI & PIM & EBF & ECB & ERSE & INF & CCR & GDPP & QES \\
\hline FDI & 1 & & & & & & & & \\
\hline PIM & 0.1398 & 1 & & & & & & & \\
\hline EBF & 0.1959 & 0.517 & 1 & & & & & & \\
\hline ECB & 0.1326 & 0.502 & 0.5805 & 1 & & & & & \\
\hline ERSE & -0.1321 & -0.0683 & -0.036 & -0.1417 & 1 & & & & \\
\hline InF & 0.0273 & 0.1859 & -0.079 & 0.0741 & -0.0271 & 1 & & & \\
\hline CCR & -0.0596 & -0.3283 & -0.2619 & -0.3524 & 0.1764 & -0.1832 & 1 & & \\
\hline GDPP & -0.1212 & -0.4162 & -0.3627 & -0.3964 & 0.3527 & -0.0549 & 0.4328 & 1 & \\
\hline QES & 0.3286 & 0.3342 & 0.3271 & 0.1479 & -0.0876 & -0.111 & -0.2016 & -0.2342 & 1 \\
\hline
\end{tabular}

Source: Authors' own calculation, 2020. CCR: country's credit score; EBF: ethical behaviors of countries' businesses; ECB: efficiency of corporate administration; ERSE: securities and conversion standard regulation; GDPP: gross domestic product per capita; INF: inflation PIM: minority shareholders' interest; QES: quality of electricity.

Table 3 below shows and discusses the results of our empirical estimates. As already mentioned, our results were based on how the selected West African countries' levels of governance structures play a vital role in attracting inflows of foreign direct investments (FDIs) and thus help us to answer our formulated questions using the dynamic panel generated model of moments (GMM). It should be noted that the number of observations in Tables 1 and 3 is different as the extreme values were omitted from the regression analysis as explained by Arellano and Bover [52]. There is a significant debate on missing variables in models, and this is summarized in Baltagi et al. [49].

We are now approaching the presentation of our results related to our formulated research questions. Based on the GMM regression (Table 3), our outcome recorded a noteworthy positive connection between the degree of minority shareholders' interest (PIM) and FDI in our selected West African countries. This outcome affirms the primary formulated research question (Q1) of our examination: Does minority shareholders' interest protection attract FDI inflows in West Africa? This is on the grounds that foreign investors are worried about amplifying their profitability, and they are similarly worried about how the host economy shields its interests. Scholars have contended that when an economy is precarious and unable to ensure the interests of minority shareholders, it discourages foreign investors from directing their extreme assets to such an economy as foreign direct ventures $[11,22]$. In addition to this, economies that seek strategies that ensure more noteworthy assurance for minority shareholders result in lower capital expenses and effectively raise support [27]. Our outcome was consistent with other studies $[24,28,39,55]$ showing that West African nations that guarantee the security of the interests of shareholders, particularly minorities, draw in a more significant level of FDI. 
Table 3. GMM System Regression Results.

\begin{tabular}{ccccccc}
\hline FDI & Coefficient & St.Err. & $\mathbf{z}$ & $\mathbf{P}>|\mathbf{z}|$ & {$[95 \%]$ Conf. } & Interval \\
\hline lagFDI & -0.1551549 & 2.323114 & -0.07 & $0.011^{* *}$ & -4.708375 & 4.398065 \\
\hline PIM & 5.607972 & 90.66289 & 0.06 & $0.00266^{* * *}$ & -183.304 & 172.088 \\
\hline EBF & 49.56777 & 190.4953 & 0.26 & $0.002 * * *$ & -323.7961 & 422.9316 \\
\hline ECB & 40.74557 & 196.4564 & 0.21 & $0.0002 * * *$ & -344.3019 & 425.7931 \\
\hline ERSE & -230.1067 & 1004.014 & -0.23 & 0.8196 & -2197.938 & 1737.724 \\
\hline INFLA & -2.240638 & 32.42629 & -0.07 & 0.945 & -65.795 & 61.31373 \\
\hline GDP & -0.1755589 & 0.6029865 & 0.29 & $0.0004 * * *$ & -1.006273 & 1.357391 \\
\hline CCR & -2.388314 & 17.42816 & -0.14 & 0.0179 & -36.54687 & 31.77025 \\
\hline QES & 116.8929 & 335.0024 & 0.35 & 0.078 & -539.6998 & 773.4857 \\
\hline Cons & 4.846616 & 1911.373 & 0 & 0.998 & -3741.375 & 3751.069 \\
\hline
\end{tabular}

Group variable: countrynum; number of obs $=153$; time variable: year; number of groups $=17$; number of instruments $=10$; obs per group: $\min =9$; Wald chi2(9) = 2.30; avg = 9.00; Prob $>$ chi2 = 0.986; $\max =9 ; \mathrm{AR}(1)=-0.30$; $\operatorname{AR}(2)=-0.24$; J-Statistics: $=17.623$; Prob $(\mathrm{J}$-stats $)=0.77$; The values in parentheses are $p$-values; values denoted by ***, **, and * represent $1 \%, 5 \%$, and $10 \%$ significant levels respectively. St.Err.; standard errors; Conf.: confidence interval. The insignificant probability (J-stats) value suggested that there is no overriding identity, and the instruments adopted are efficient and do not correlate with the error term. Source: Authors' own calculation, 2020.

In addition to this, our results show a noteworthy positive connection between ethical behaviors of countries' businesses (EBF) and the degree of FDI inflows into our selected West African countries. This outcome affirms our subsequent research question $(\mathrm{Q} 2)$ on whether the extent of profoundly ethical local firms assists West African countries in attracting the inflows of foreign direct investments. Empirically speaking, West African countries that give high premiums to their local organizations to act ethically have the advantage of a progressively higher increase of the inflows of foreign direct investment. Although economic writings have of late centered mostly on the role of institutional structures at the nation level in guaranteeing the strength of foreign proprietorship [37], in a seriously competitive business condition, business ethics could assume a crucial role in pulling in foreign direct investments. The ongoing worldwide money-related emergency connected to different company scandals has featured the significance of ethical, monetary, and accounting reporting codes and standards to guarantee that companies are being fair and transparent, which forestalls extortion and improves the confidence of investors. This outcome affirms the discoveries that economies described by firms to adhere to codes and ethics and stick to dependable strategic approaches are viewed as significant resources that help pull in foreign direct investment into West African countries [24,33].

Furthermore, our investigation recorded a noteworthy positive connection between the efficiency of corporate administration (ECB) and the degree of FDI in our chosen West African nations. This outcome answers the third inquiry (Q3) of this examination of whether the presence of a successful corporate administration can assist with drawing in more FDI to an economy. This implies that when business councils from the West African countries are viable, the degree of foreign direct interest in these countries expands. Most West African nations have discovered these principles and regulations; however, enforcing requirement is dangerous $[24,37,48]$. One result of this is the availability of a strong company's board of directors (BODs) that helps to build investors' trust in these countries. This is on the grounds that most investors accept that their investments would be safe with the successful guidance of effective and efficient executives [50]. This finding affirms the discoveries that foreign investors are prepared to direct their assets or stretch out their investments to nations characterized by powerful corporate administration $[24,34,56]$.

Moreover, our study uncovered a negative connection between the level of foreign direct investment and effectiveness of securities and conversion standard regulation (ERSE) for our selected West African countries. This result was surprising as it conflicted with our last inquiry (Q4), which was 
whether the adequacy of securities and foreign trade regulations in general influence the degree of FDI in an economy. This outcome might be a result of political obstruction in the definition, execution, and assessment of securities and trade regulations. Securities and exchanges are relied upon to be free and self-governing, without any type of political obstruction in the satisfaction of their commitments by the administrations of West African countries [53]. In this way, economies characterized by steady political impedance in the activities of forex and securities exchanges have a likelihood to pull in low foreign investments [11]. One can imagine that our selected West African economies are characterized by unjustified administrative weights, capricious arrangements, and an absence of responsibility with respect to their legislatures [53]. These events, therefore, reduce investor confidence in economies, which ultimately reduces the degree of foreign direct interest in the selected West African countries. This was consistent with the study by Lee et al. [24]

Finally, the lag of FDI and gross domestic product (GDP) reported a negative but statistically significant relationship with the inflows of FDI to West African countries. The significance of the lag variable confirms that it is an important instrumental variable as suggested by Barrell and Nahhas [19]. However, the negative relationship deviates from the existing literature. It can be explained that a negative relationship indicates no persistence in FDI inflows to West African countries. Countries that have high GDP are seen to be developed and as such have little or no investment opportunities. However, low GDP countries are viewed as countries with potential, since there are a lot of investment avenues to explore. Along these lines, the assumption that supports the approach toward FDI in most developing nations including West Africa is that a liberal arrangement toward multinational enterprises (MNEs) is adequate to guarantee constructive effects suggested by Agosin and Machado [17]. The inflation and level of a country's credit scores (CCR) demonstrated a negative relationship with FDI. This was consistent with the study by Appiah-Kubi et al. [11]. The quality of electricity (QES) showed a positive relationship with FDI. However, these variables are insignificant in determining the level of FDI in West African countries. This conflicts with the examination of Smutka, Pawlak, Kotyza, and Svatoš [57].

\section{Conclusions and Recommendations}

The objective of the paper was to ascertain a correlation between corporate governance structures at a country level and FDI in West Africa countries via the estimation technique of difference dynamic panel generalized method of moments (GMM). This study was carried out for 17 West African countries from 2009 to 2018. Our outcomes show that economies displaying ethical firms will in general pull in more FDI. Empirically speaking, West African countries that give high premiums to their local organizations to act ethically have the advantage of progressively higher increase of the inflows of foreign direct investment. The ongoing worldwide money-related emergency connected to different companies' scandals has featured the significance of ethical, monetary, and accounting codes and standards to guarantee companies are being fair and transparent, which forestalls extortion and improves confidence of investors. Furthermore, our outcomes show that when the boards of organizations in the economy are successful in managing, this adds to a significant increase of FDI inflows into the economy. This implies that when business councils from the West African countries are viable, the degree of foreign direct investment in these countries expands. Most West African nations have discovered these principles and regulations; however, enforcing requirement is dangerous. One result of this is the availability of strong boards of directors that help to build investors' trust in these countries. This is on the grounds that most investors accept that, with successful guidance of effective and efficient executives, their investments would be safe. The discoveries further show that economies displaying solid minority shareholders' interest protection will in general draw in more foreign direct investment. This is because foreign investors are worried about amplifying their profitability; they are similarly worried about how the host economy shields its interests. Scholars have contended that when an economy is precarious and unable to ensure the interests of minority shareholders, it discourages foreign investors from directing their extreme assets to such an economy as foreign direct 
ventures. Be that as it may, our examination uncovers the insignificant link between effectiveness of securities and stock exchange regulation on the inflows of FDI. This outcome can be ascribed to political impedance in the detailing, execution, and assessment of securities and stock trade regulations.

Concerning political ramifications, the outcomes unequivocally propose that dependence on nation-level corporate governance structures by West African countries can make a landmass that will draw in important foreign direct investment for financial development. We recommend the setting up of practical corporate governance structures in African economies without political mediation to accomplish the objective of utilizing foreign direct investment to mitigate poverty by 2025 under the Millennium Development Goals. The accompanying explicit measures are proposed to African economies. First, West African countries should provide a guarantee that proper implementation measures are set up to ensure that the privileges of minority shareholders can be accomplished by fortifying the institutional structures in their economies. Second, West African nations should endeavor to urge domestic organizations to work ethically through the required foundation of morals and consistence units in associations. Third, they should guarantee the alleviation of approach impedance in the detailing and usage of corporate regulations. Moreover, African economies should publicly introduce and supply guidelines, policies, administrative formalities, and preferential treatments in provinces through means of communication (televisions, radios, newspapers, et cetera). Lastly, African countries should periodically hold economic forums to collect foreign investors' ideas and economic experts' policy implications for attracting FDI inflows.

Despite the useful findings, there were some limitations to our results, which must be dealt with to improve future research in this area. The first limitation was a lack of long-term longitudinal data in the sample of the West African countries. This has been a common problem with several studies on developing countries, which highlights the need for more extensive, better-quality data on such economies. Future research should take into consideration incidence of corruption and freedom of the press of our sampled West African countries when establishing the relationship between corporate governance and FDI. This may limit the reliability of our results. To overcome this issue, similar studies can expand our model to include both incidence of corruption and freedom of the press.

Author Contributions: Conceptualization, S.N.K.A.-K.; Data curation, S.N.K.A.-K. and O.Z.; Formal analysis, S.N.K.A.-K. and S.B.K.; Funding acquisition, K.M. and M.M.; Investigation, S.N.K.A.K. and S.B.K.; Methodology, S.N.K.A.-K. and S.B.K.; Project administration, M.M. and L.P.; Resources, K.M., L.P., J.P. and O.Z.; Software, L.P., J.P. and O.Z.; Supervision, K.M. and M.M.; Validation, J.P.; Visualization, K.M.; Writing-original draft, S.N.K.A.-K.; Writing-review \& editing, K.M. and S.B.K. All authors have read and agreed to the published version of the manuscript.

Funding: This paper was supported by the Internal Grant Agency (IGA) of the Faculty of Economics and Management, Czech University of Life Sciences Prague, grant no. 2020A0004 "Foreign direct investment and corporate governance structures: Evidence from Africa".

Conflicts of Interest: The authors declare no conflict of interest.

\section{References}

1. United Nations Economic Commission for Africa. The Economic and Social Council Official Records in 2016. Available online: https://www.un-ilibrary.org/united-nations/official-records-united-nations-economic-andsocial-council_b3fc44d4-en (accessed on 2 January 2020).

2. Dupasquier, C.; Osakwe, P.N. Foreign direct investment in Africa: Performance, challenges, and responsibilities. J. Asian Econ. 2006, 17, 241-260. [CrossRef]

3. Musila, J.W.; Sigue, S.P. Accelerating foreign direct investment flow to Africa: From policy statements to successful strategies. Manag. Financ. 2006, 32, 577-593. [CrossRef]

4. Chuhan, P.; Pérez-Quirós, G.; Popper, H. International Capital Flows: Do Short-Term Investment and Direct Investment Differ? Policy Res. Work. Pap. 1996, 16-69. [CrossRef]

5. Calvo, G.A.; Leiderman, L.; Reinhart, C.M. Inflows of Capital to Developing Countries in the 1990s. J. Econ. Perspect. 1996, 10, 123-139. [CrossRef] 
6. Fernández-Arias, E.; Montiel, P.J. The Surge in Capital Inflows to Developing Countries: An Analytical Overview. World Bank Econ. Rev. 1996, 10, 51-77. [CrossRef]

7. Globerman, S.; Shapiro, D.; Tang, Y. Foreign direct investment in emerging and transition european countries. Int. Financ. Rev. 2006, 6, 431-459. [CrossRef]

8. Dyck, A. Privatization and Corporate Governance: Principles, Evidence, and Future Challenges. World Bank Res. Obs. 2001, 16, 59-84. [CrossRef]

9. Collier, P.; Cust, J. Investing in Africa's Infrastructure: Financing and Policy Options. Annu. Rev. Resour. Econ. 2015, 7, 473-493. [CrossRef]

10. Anyanwu, J.C. Characteristics and Macroeconomic Determinants of Youth Employment in Africa. Afr. Dev. Rev. 2013, 25, 107-129. [CrossRef]

11. Appiah-Kubi, S.N.K.; Mansoor, M.; Zaganjori, O.; Sahatqija, O.; Malec, K. The Impact of Macroeconomics variables on the inflows of FDI in the least Developed West African Countries. In Agrarian Perspectives XXVII, Business Scale in Relation to Economics; Czech University of Life Sciences Prague: Prague, Czech Republic, 2019; Volume XXVII, ISBN 978-80-213-2973-7. ISSN 2464-4781 (Online).

12. Johnson, A. The Effects of FDI Inflows on Host Country Economic Growth. The Royal Institute of Technology; Centre of Excellence for studies in Science and Innovation. Available online: http://www.infra.kth.se/cesis/ research/publications/workingpapers (accessed on 2 January 2020).

13. Love, I.; Klapper, L. Corporate Governance, Investor Protection, and Performance in Emerging Markets. Policy Res. Work. Pap. 2002, 13, 15-20. [CrossRef]

14. Borensztein, E.; De Gregorio, J.; Lee, J.-W. How does foreign direct investment affect economic growth? J. Int. Econ. 1998, 45, 115-135. [CrossRef]

15. Saini, N.; Singhania, M. Determinants of FDI in developed and developing countries: A quantitative analysis using GMM. J. Econ. Stud. 2018, 45, 348-382. [CrossRef]

16. Van Bon, N. The role of institutional quality in the relationship between FDI and economic growth in vietnam: Empirical evidence from provincial data. Singap. Econ. Rev. 2019, 64, 601-623. [CrossRef]

17. Agosin, M.R.; Machado, R. Foreign Investment in Developing Countries: Does it Crowd in Domestic Investment? Oxf. Dev. Stud. 2005, 33, 149-162. [CrossRef]

18. Kuzmina, O.; Volchkova, N.; Zueva, T. Foreign direct investment and governance quality in Russia. J. Comp. Econ. 2014, 42, 874-891. [CrossRef]

19. Barrell, R.; Nahhas, A. Economic Integration and Bilateral FDI Stocks: The Impacts of NAFTA and the EU; LSE Research Online Documents on Economics 90372; London School of Economics and Political Science, LSE Library: London, UK, 2018; Volume 14, pp. 7-9. Available online: https://EconPapers.repec.org/RePEc:ehl: lserod:90372 (accessed on 15 April 2020).

20. Anghel, B. Do Institutions Affect Foreign Direct Investment; International Doctorate in Economic Analysis: Barcelona, Spain, 2005; Volume 13, pp. 2-40. Available online: https://www.researchgate.net/profile/ Brindusa_Anghel/publication/228622178 (accessed on 16 December 2019).

21. Bissoon, O. Can Better Institutions Attract More Foreign Direct Investment (FDI)? Evidence from Developing Countries. In International Conference on Applied Economics; Istanbul, Turkey, 2011; Volume 59, pp. 59-70. Available online: https://pdfs.semanticscholar.org/efe6/6fd16f2c18ad0cc0929100e14c1a9d7e430c.pdf (accessed on 16 January 2020).

22. Dunning, J. Global Capitalism, FDI and Competitiveness; Edward Elgar Publishing: Northampton, Massachusetts, USA, 2002; Volume 2, Available online: https://books.google.cz/books?hl=en\&lr=\&id=V4koUdv0UzQC\& oi=fnd\&pg=PR6\&dq (accessed on 22 December 2019).

23. Loree, D.W.; Guisinger, S.E. Policy and Non-Policy Determinants of U.S. Equity Foreign Direct Investment. J. Int. Bus. Stud. 1995, 26, 281-299. [CrossRef]

24. Addison, T.; Heshmati, A. The new global determinants of FDI flows to developing countries: The importance of ICT and democratization. Monet. Integr. Mark. Regul. 2004, 4, 151-186. [CrossRef]

25. Globerman, S.; Shapiro, D. Governance infrastructure and US foreign direct investment. J. Int. Bus. Stud. 2002, 34, 19-39. [CrossRef]

26. Biglaiser, G.; DeRouen, K. Economic Reforms and Inflows of Foreign Direct Investment in Latin America. Lat. Am. Res. Rev. 2006, 41, 51-75. [CrossRef]

27. Gani, A. Governance and foreign direct investment links: Evidence from panel data estimations. Appl. Econ. Lett. 2007, 14, 753-756. [CrossRef] 
28. Lee, H.; Staats, J.L.; Biglaiser, G. The importance of legal systems for portfolio investment in the developing world. Int. Area Stud. Rev. 2012, 15, 339-358. [CrossRef]

29. Jones, I.; Pollitt, M. Understanding How Issues in Corporate Governance Develop: Cadbury Report to Higgs Review. Corp. Gov. Int. Rev. 2004, 12, 162-171. [CrossRef]

30. Valdés, A.; Foster, W. Making the Labor Market a Way out of Rural Poverty. Rural and Agricultural Labor Markets in Latin America and the Caribbean. In Background Paper for the World Development Report; World Bank: Washington DC, USA, 2008.

31. Mitton, T. A cross-firm analysis of the impact of corporate governance on the East Asian financial crisis. J. Financ. Econ. 2002, 64, 215-241. [CrossRef]

32. Cook, P.; Kirkpatrick, C.; Minogue, M.; Parker, D. Competition, Regulation and Regulatory Governance: An Overview; Edward Elgar Publishing: Northampton, MA, USA, 2013; pp. 3-35.

33. Agyemang, O.S.; Gbettey, C.; Gatsi, J.G.; Acquah, I.S.K. Country-level corporate governance and foreign direct investment in Africa. Corp. Gov. Int. J. Bus. Soc. 2019, 19, 1133-1152. [CrossRef]

34. Aguilera, R.V.; Cuervo-Cazurra, A. Codes of Good Governance Worldwide: What is the Trigger? Organ. Stud. 2004, 25, 415-443. [CrossRef]

35. La Porta, R.; Lopez-De-Silanes, F.; Shleifer, A.; Vishny, R.W. Agency Problems and Dividend Policies around the World. J. Financ. 2000, 55, 1-33. [CrossRef]

36. McLean, R.D.; Zhang, T.; Zhao, M. Why Does the Law Matter? Investor Protection and Its Effects on Investment, Finance, and Growth. J. Financ. 2012, 67, 313-350. [CrossRef]

37. Balasubramanian, N.; Black, B.S.; Khanna, V. The relation between firm-level corporate governance and market value: A case study of India. Emerg. Mark. Rev. 2010, 11, 319-340. [CrossRef]

38. Kim, K.A.; Kitsabunnarat-Chatjuthamard, P.; Nofsinger, J.R. Large shareholders, board independence, and minority shareholder rights: Evidence from Europe. J. Corp. Financ. 2007, 13, 859-880. [CrossRef]

39. A Reese, W.; Weisbach, M.S. Protection of minority shareholder interests, cross-listings in the United States, and subsequent equity offerings. J. Financ. Econ. 2002, 66, 65-104. [CrossRef]

40. Kasser, T.; Sheldon, K.M. Time Affluence as a Path toward Personal Happiness and Ethical Business Practice: Empirical Evidence from Four Studies. J. Bus. Ethic 2009, 84, 243-255. [CrossRef]

41. Bardy, R.; Drew, S.; Kennedy, T.F. Foreign Investment and Ethics: How to Contribute to Social Responsibility by Doing Business in Less-Developed Countries. J. Bus. Ethic 2002, 106, 282. [CrossRef]

42. Okpara, O.J. Perspectives on corporate governance challenges in a Sub-Saharan African economy. J. Bus. Policy Res. 2010, 5, 110-122.

43. Miletkov, M.; Poulsen, A.B.; Wintoki, M.B. The role of corporate board structure in attracting foreign investors. J. Corp. Financ. 2014, 29, 143-157. [CrossRef]

44. Daude, C.; Stein, E. The quality of institutions and foreign direct investment. Econ. Politics 2007, 19, 317-344. [CrossRef]

45. Agyemang, O.S.; Fantini, G.; Ansong, A. Unearthing the Integral Determinants of Foreign Ownership Prevalence of Companies in Africa: Role of Country-level Governance. J. Afr. Bus. 2016, 17, 225-253. [CrossRef]

46. Kirkpatrick, C.; Parker, D.; Zhang, Y.F. Foreign direct investment in infrastructure in developing countries: Does regulation make a difference? Transnatl. Corp. 2006, 15, 143-171.

47. Cai, P.; Kim, S.J.; Gan, Q. The effects of sovereign credit rating on foreign direct investment. In Proceedings of the 15th World Business Research Conference, Tokyo, Japan, 25-26 February 2016; pp. 25-26. Available online: http://www.business.uwa.edu.au/_data/assets/pdf_file/0007/2938084/The-effect-of-sovereign-creditrating-on-FDI.pdf (accessed on 7 January 2020).

48. Kim, S.-J.; Wu, E. International bank flows to emerging markets: Influence of sovereign credit ratings and their regional spillover effects. J. Financ. Res. 2011, 34, 331-364. [CrossRef]

49. Baltagi, B.H.; Liu, L. Estimation and prediction in the random effects model with AR (p) remainder disturbances. Int. J. Forecast. 2013, 29, 100-107. [CrossRef]

50. Holtz-Eakin, D.; Rosen, H. Federal deductibility and local property tax rates. J. Urban Econ. 1990, 27, 269-284. [CrossRef]

51. Arellano, M.; Bond, S. Some Tests of Specification for Panel Data: Monte Carlo Evidence and an Application to Employment Equations. Rev. Econ. Stud. 1991, 58, 277. [CrossRef] 
52. Arellano, M.; Bover, O. Another look at the instrumental variable estimation of error-components models. J. Econ. 1995, 68, 29-51. [CrossRef]

53. Bokpin, G.A.; Mensah, L.; Asamoah, M.E. Legal source, institutional quality and FDI flows in Africa. Int. J. Law Manag. 2017, 59, 687-698. [CrossRef]

54. Romano, R. Empowering Investors: A Market Approach to Securities Regulation. Yale Law J. 1998, $107,2359$. [CrossRef]

55. Maitah, M.; Saleem, N.; Malec, K.; Boubaker, M.; Gouda, S. Economic value added and stock market development in Egypt. Asian Soc. Sci. 2015, 11, 126-134. [CrossRef]

56. Toth, D.; Maitah, M.; Stefkova, M. Comparative research of youth employment in France and the Czech Republic. Res. J. Appl. Scis. 2014, 9, 1009-1015. [CrossRef]

57. Smutka, L.; Pawlak, K.; Kotyza, P.; Svatos, M. Department of Economics and Economy Policy in Agribusiness, Faculty of Economics and Social Sciences, Poznan University of Life Sciences; Department of Economics, Faculty of Economics and Management, Czech University of Life Sciences Prague Polish Sugar Industry Development. Agris On-Line Pap. Econ. Inform. 2018, 10, 71-90. [CrossRef]

(C) 2020 by the authors. Licensee MDPI, Basel, Switzerland. This article is an open access article distributed under the terms and conditions of the Creative Commons Attribution (CC BY) license (http://creativecommons.org/licenses/by/4.0/). 